\title{
Language, Thought and Culture: Links to Intercultural Communicative Competence
}

\author{
Denise Lussier (McGill University)
}

\begin{abstract}
We live in a world where many countries are at war, where religious and ethnic conflicts tend to intensify in spite of sustained effort from governments and inter-governments, where solitudes and tensions between linguistic communities still prevail. In a context where geo-political interests predominate, how do we view cultural and intercultural issues? How can we promote values and attitudes that recognize experiences of diversity and openness to other cultures? Can institutions such as schools and universities promote social cohesion through education?

These issues are essential to mankind but they have to be looked upon with logical coherence.This article reviews existing theories, definitions and a conceptual framework to the development of ICC which involves cognitive, affective and psychological factors, and intends to capture the interrelations that are embedded in language, thought and culture. It argues that language competence needs to address not only the linguistic, sociolinguistic and pragmatic/discourse elements of langue but should also integrate (inter)cultural interactions, the development of (inter)cultural representations and transactions between individuals in the learning process.
\end{abstract}

\begin{abstract}
Résumé
Nous vivons dans un monde dans lequel plusieurs pays sont en guerre; dans lequel les conflits religieux et ethniques tendent à s'intensifier en dépit des efforts constants des gouvernements et des agences intergouvernementales; un monde dans lequel les isolements et tensions entre les communautés linguistiques persistent encore. Alors, dans un contexte où les intérêts géopolitiques dominent, comment voyons-nous les problèmes culturels et interculturels ? Comment pouvons-nous promouvoir des valeurs et attitudes qui reconnaissent l'expérience de la diversité et l'ouverture sur les autres cultures ? Des institutions telles que les écoles et les universités peuvent-elles exhorter à une cohésion sociale à travers l'éducation?

Ces questions sont essentielles à l'humanité ; cependant, elles doivent être considérées avec une cohérence logique. Cet article passe en revue des théories existantes, des définitions et un cadre conceptuel au développement des CIC qui implique des facteurs cognitifs, affectifs et psychologiques; et projette de capter l'essence des interrelations qui sont incorporés au langage, à la pensée et à la culture. Cet article soutient que la compétence linguistique doit se pencher non seulement sur les éléments linguistiques, sociolinguistiques et pratiques/ discursives de la langue ; mais devrait également intégrer des interactions (inter)culturelles, le développement des représentations et transactions (inter)culturelles entre les individus en processus d'apprentissage.
\end{abstract}

\section{INTRODUCTION}

Within this new era of pluri-lingual and multicultural societies, one word predominates: globalization. It is associated with the rapid development of communication, new technologies, political or economic reforms and the mobility of people as a new reality. All of these new societal considerations raise complex issues for all nations. These changes also bring new challenges to educators and educational systems. Some questions become crucial. With the rise 
of plurilingual and multicultural societies, are cultural and religious boundaries clashing with geographical borders? Are cultural representations within and across countries becoming fluid, changing and unstable? In times where culture seems to be considered as a simple commodity among others in the common market, can institutions such as schools promote social cohesion through education?

It seems as though a third culture, through television, cinema and the internet, exists above the control of the nations and has created a transnational languaculture that accounts for the existence of the same trends, habits and even values in different points of the globe (Agar, 1994). Consequently, national and ethnic identities have become more permeable and they influence each other. This implies a constant dialogue that calls into question granted assumptions, habits and values established at a national level (Robertson, 1995; Featherstone, 1995, as quoted in Guillerme-Durate, 2000:183)

The purpose of the article is to seek out different viewpoints expressed by authors in reference to the integration of the intercultural dimension in language teaching; knowing that there could not be communicative competence without the expression of intercultural communicative competence (ICC). Firstly, it introduces critical issues in language education, looking at language in relation to thought and culture. Secondly, it examines various theories, definitions and a proposed conceptual framework (Lussier, 1997; in press). Finally, it suggests some directions for research that bear on empirical studies conducted to ensure the validity of the conceptual framework and its application in language teaching and testing (Lussier, Auger, Clément, Lebrun-Brossard, 2000-2008).

\section{CRITICAL ISSUES IN LANGUAGE EDUCATION}

There is an undeniable link between language, thought and culture (Stern, 1983). Language represents not only the primary means of communication between people of different cultures, but its infinite capacity to generate symbolic orders of power relations shapes individual perceptions and visions of social worlds (Bourdieu, 1982, 1994; Jacquinot, 1987). Language allows us to constantly rethink the issue of the construct of cultural representations. Mental representations are generated; that is, schemata of perception and appreciation, acts of knowledge and recognition which are constructed by individuals according to their own interests, presuppositions and evaluative orientations. Also, the connection between an object or a situation and the way that it is represented is completely cultural, which creates difficulties with intercultural communication (Jacquinot, 1987). Moreover, negative representations of another culture (xenophobia) have historically been formed through the spread of 
discourse. Thus, language acts are not pure and neutral linguistic elements (Vygotsky, 1962). Verbal thoughts are historically and culturally determined. They must be conceptualized as cultural tools and representations of the culture. In this perspective, it is important to view language teaching and learning as an entry to discover another culture. It embodies, by its nature, the presence of the other culture and contact with alterity, the act of noticing differences and similarities and becoming aware of Otherness without changing into someone else. It involves an important part of mediation in the interactions with members of the other culture.

As pointed out by many authors, language and other semiotic systems are not only carriers of culture; they are culture (Geertz 1975:9). It is in using linguistic traits and other signs that the child acquires meanings, and gradually recognizes the meanings of signs and will internalize them (Vygostky, 1971). Culture is active and dynamic. It deconstructs the world through naming, describing, reporting and confronting with both present and past social and personal values, and reconstructs it through design and planning, through fiction myth and narration. Learning a foreign language is essentially learning to interact as an 'intercultural competent speaker'.

According to Lussier (1997), language is the means by which culture and representations that learners have of other cultures are spread. Language is not only a linguistic code to master (the linguistics perspective), a social act (the sociolinguistic perspective) and a cognitive process (the psycholinguistics perspective). It is also an intercultural process (Vygotsky, 1962; Bourdieu, 1982). Lately, it has been closely linked to intercultural communicative competence (Byram, 1997; Lussier, 1997, 2008). This new aspect of teaching is not questioned any more, neither in language education nor in social sciences. But language teaching has interacted for a long time with linguistics, sociolinguistics and psychology. Social sciences, anthropology, ethnography and language teaching have only recently come into contact with each other even if many writings have focused on the connection between language and society before (Malinowsky, 1923; Sapir, 1934, 1970; Seelye 1973; Stern 1981).

Nowadays, theoretical models have integrated 'culture' as an important part of language education and training but it is often viewed through the humanistic approach based on cognitive knowledge of civilization. Cultural and intercultural understandings and cross-cultural interactions, as necessary components of language pedagogy, need to be integrated with logical coherence. In 1981, Stern recognized the need for a multidimensional curriculum in language pedagogy, with the inclusion of a distinct syllabus on "culture", more complex than the sociolinguistic component, as defined in a descriptive model of 
the communicative approach (Canale and Swain, 1980) and working models developed by Bachman (1991) and the Council of Europe (2001).

In spite of these advances, the anthropological and social concept of culture has been difficult to integrate in language teaching. A number of issues remain but there is no doubt, language, thought and culture are interrelated. To study them separately fails to capture the interrelations that are embedded among them. 'Interacting effectively' means accomplishing a negotiation between people. It implies the criss-crossing of identities and the positions to which they are summoned (Hall, 1969:13-14).

There are still many issues to address in terms of the language/culture relation, the nature of cultural representations linked to social thought and the interrelations which exist among each of these concepts. The study of language, thought and culture as a harmonious whole would lead to an overall better understanding of their interdependence, and thereby favor the development of language teaching and language learning models that would foster the development of ICC. Learners should be committed to turning language encounters into intercultural relations (Guilherme-Durate, 2000) and to developing positive cultural representations of others and other cultures. It should also invite learners to use cultural mediation in situations of misunderstandings, lack of incomprehension, and even conflicts. Such a new approach to language teaching must take into consideration affective and psychological factors as well as cognitive factors. For the learners, it requires the development of certain knowledge, skills and attitudes, not considered in former conceptual frameworks. The three assumptions linked to the concepts of language, thought and culture and the underlying theories need to be addressed.

\section{Language and the cultural component}

The statement of the problem is: When teaching languages, educators tend to underestimate the (inter)cultural component and social interactions in communication in terms of learning outcomes, language acquisition process, curriculum design and pedagogical methodologies.

Modern linguistic theories have evolved since Saussure's concepts of langue/parole (1916). First, there was the grammar-based approach organized on the basic components of linguistics and the way to combine phonological and morphological forms, syntactic patterns and lexical items to form grammatical and meaningful sentences. In 1957, Skinner proposed an analysis of verbal behavior and insisted on the formation of habits in language learning. Then, in 1965, Chomsky, against traditional and structural linguistics, introduced the terms competence/performance, considering essential the socio-semantic 
approach to aspects of language and language use. Chomsky's contribution puts into perspective a theory of competence and a theory of performance, the former being concerned with the linguistic rules, mostly the knowledge of grammar and of other aspects of language that can generate and describe the sentences of a language; and the latter, performance, being a theory of interaction between the theory of grammar and the set of non-grammatical psychological factors bearing on language use such as the actual use of language in concrete situations.

These new developments led linguists, sociolinguists and anthropologists, such as Savignon (1972) and Hymes (1972) to point out the lack of consideration for 'appropriateness' or the sociocultural significance of an utterance in a given context. Hymes (1972), after his analysis of the ethnography of speaking, introduced a broader notion of competence in terms of communicative competence. In 1978, Widdowson referred to the usage and use of the language. The notions of ability and of communication skills linked to communicative competence also led to the introduction of language functions and notions (Van Ek, 1976; Coste, 1978) and brought about the development of new types of syllabi such as the functional/notional and the situational syllabus (Morrow, 1977). Munby (1978), in his model of communicative competence, presented three major components: a socio-cultural orientation based on the work of Hymes, a socio-semantic view of linguistic knowledge based on Halliday's theories (1973) and rules of discourse. It is only in 1980 that Canale and Swain introduced the first Theoretical Bases of Communicative Competence Approaches to Language Teaching and Testing. The proposed theoretical framework includes linguistic, strategic and sociolinguistic competence. This last one is defined as the ability to use language in social contexts. It is made up of two sets of rules: sociocultural rules of use in ways which utterances are produced and understood appropriately and rules of discourse with respect to cohesion and coherence. In 1983, Canale moves the rules of discourse under a new component, the "discourse competence" as the ability to produce utterances appropriately in terms of coherence and cohesion.

Two existing models (Bachman 1991: Council of Europe, 2001) still refer to a 'sociolinguistic' component. In Bachman's model (1991), the 'sociolinguistic component' takes into account sensitivity to differences in dialect or variety; to differences in register; to naturalness; and to the ability to interpret cultural references and figures of speech. In the recent Common European Framework of Reference for Languages: Learning, Teaching and Assessment (Council of Europe, 2001:118), 'sociolinguistic competence' is concerned with the knowledge and skills required to deal with the social dimension of language use. Since language is a sociocultural phenomenon, it is viewed as linguistic 
markers of social relations, politeness conventions, expressions of folk-wisdom, register differences, and dialect and accents.

However, within new plurilinguistic and pluricultural societies, such competencies seem superficial. They address visible aspects of cultures, stereotypes, artifacts and elements of folklore. They are restrictive and cannot lead to openness to others and other cultures. Labov $(1966,1972)$ was one of the first to consider that sociolinguistics should not be a new component to the linguistic dimension since the highest level of linguistic competence should include the competence of organizing utterances and using them in situational and verbal contexts appropriate to their proper use.

Many researchers and theorists from different fields of language education have rejected these restrictive approaches and introduced the sociocultural component (Lussier, 1995; Byram and Zarate, 1997). Two other models could have been retained: Moirand's model (1982) which includes 'cultural competence' as an essential component of language competence and Stern's model (1981) which proposes a multidimensional curriculum including four syllabi, with a specific syllabus on "culture".

All these concerns between language as a social act and language as a linguistic system led to the concept of "language awareness". It was defined by James and Garrett (1991) in the early 1980s with the pioneering work of Hawkins $(1981,1984)$ and the foundation of the so-called 'British Language Awareness Movement'. It is seen as a person's sensitivity to and conscious awareness of the nature of language and its role in human life (Donmall, 1985:7). It is specified in reference to three broad parameters: cognitive (developing awareness of patterns of language), affective (forming attitudes), and social (improving students' effectiveness as citizens or consumers). It was an umbrella term grouping together different understandings and it led to a multiplicity of syllabi and courses. But, as stated by Byram (1989:36), language awareness, by definition, is limited to language and to recognition of the importance of minority languages rather than active learning of them. It has the merit of introducing new ways of looking at intercultural issues and it led researchers to seek new concepts such as "cultural awareness" and "critical awareness" as described later by Guilherme-Durate (2000). Many authors propose new models to include an intercultural dimension to language education (Byram, 1989; Byram and Zarate, 1997; Lussier. 1997, 2008; Byram, 1997).

Nowadays, some linguists are still concerned with the sociolinguistic dimension. Calvet $(1993,1999)$ comments on one of the major claims towards the definitions of language; to allow us to believe that a neutral rapport exists between the locutor and the language. There is a whole set of attitudes and 
sentiments which make superficial, the study of language as a simple tool to communicate with. Therefore, there is an importance in explaining and accounting for social communication in all its complexity. Even in 1975, Calvet was considering "linguistic production as the production of individuals, bringing an individual history and a collective history, and experiencing exchanges which are affective, hierarchic, relying on power, concurrence and domination..." He is not the only linguist to claim the notoriously dismal achievements in language teaching after the rejection of what was called the "behavioral" view of language. Moving from a linguistic-based approach to a communicative-based approach allowed us to believe that putting the focus on communicative competence "with an explicit contextual and sociolinguistic competence would cover the social meaning or value of a govern utterance" (Canale \& Swain, 1980:16). Nevertheless, the model failed the necessity of weaving together cultural elements and an "intercultural" component of communicative competence. So far, linguistic proficiency, when referring to the sociolinguistic components, has put emphasis mostly on determined behavioral conventions, mismatching, misunderstandings, turn-taking, expressions of politeness and some cultural points at the analytical level (Council of Europe, 2001; Byram and Morgan 1994:8). As questioned by Melde (1987:118) and Byram and Morgan (1994), it does not seem that "foreign language acquisition research can make reasoned statements about the contents of foreign language teaching, since it does not yet have a grasp of the connections, relevant to the contents, between communicative action and the foreign language way of life". As mentioned by Van Dijk (1997), there is the need to study interactions among individuals and discourse, verbal and non-verbal, as social interactions since representations are constructed as individuals interact and come in contact with each other and other cultures in particular contexts. New studies (Di Pietro and Muller 1997, 2001) tend to understand the diversity of languages and to build on the "construct of the image of "Otherness" in order to propose a new paradigm in the research on the acquisition of the linguistic code. Some work has been done, bringing the field of semiology into language pedagogy. It is a promising field to the study of discourse and text analysis. Texts are not only printed, visual or aural. They are alive. In fact, their study is not only about "textuality" or "intertextuality", but also about "subtextuality". That is, the hidden messages and values that are transmitted through cultural artifacts, attitudes or images we confront from day to day (Agger, 1992:90 in Guillerme-Durate, 2000:51). No textbook should be neutral when teaching another language. It should bring new knowledge, new considerations into the existing world of the learner in order to help him/her decentralize and restructure cultural knowledge and representations of Otherness. 
Texts should be studied in terms of the cultural signs they carry. Doing so would bring the learner to reflective thinking while learning at the same time the structures of the target language. Unfortunately, textbooks, too often, do not give such opportunity to the learner. Many studies report on a lack of cultural content in terms of 'savoir-être' and question the emphasis given to the presentation of culture as isolated capsules at the end of a learning unit, mostly based on knowledge or artificial characteristics, such as folklore, artifacts and products of the target culture and people (Lussier, 1992). Moreover, teachers have not been educated in their in-service training to look beyond these superficial aspects of language and so far, they cannot rely on solid background to approach this new field of pedagogy. Cultural studies experience the same process that existed when teachers were introduced to the concept of communicative competence (Hymes, 1972) and the presentation of the first theoretical bases to work with (Canale and Swain, 1980). For many years, everyone in language education knew there was a new way of approaching the teaching/learning of a foreign language but no adapted methodology and referential textbooks would allow them for a period of time to evolve in that direction. The need to go beyond the mastery of the linguistic code and to view communication as a social act, as a mental activity or even as a new culture to acquire is a complex process. It supposes the understanding of the construct of mental representations. It implies the study of social interaction and discourse. No other semiotic code is as explicit as natural language in the expression of meanings, knowledge, opinions and various social beliefs in order to understand the role played by social actors (Van Dijk, 1998:192).

\section{Social thought as the expression of cultural representations}

The statement of the problem is: When teaching languages, learning is too often limited to the visible elements of cultural representations, such as stereotypes, artifacts and folk aspects.

Studies have reported that linguistic competence is not a good predictor of communicative competence (Upshur, 1968; Oller and Obrecht, 1969; Savignon 1972; Tucker, 1974) and that other factors originating from sociology and psychology may be more influential. In language learning, studies on learning factors such as age (Penfield, 1965; Lenneberg 1967) and studies on attitudes and motivation by Gardner \& Lambert $(1965,1972)$ and on ethnicity and contact (Clément, 1979) have contributed to emphasize the importance of affective and psychological factors in language acquisition processes. Sociology has been concerned with sociocultural variables to have influence on individuals, such as age, sex and with theories of social organization, and descriptions of 
social groups. In addition, social psychology has been long interested in crosscultural differences in perception, evaluation, personality, identity and cognition. In 1984, Lussier studied the impact of intercultural and interlinguistic exchange programs on motivation, attitudes and language performance compared to traditional systems of language education. Even within a seven-day exchange program, the importance of affective and psychological factors is highly significant. Sociocultural and psycholinguistic factors play an essential role, as important as linguistic factors in the acquisition of a second language. Even though linguistic and intercultural exchange programs might not substitute for teaching, they play a complementary role in the development of ICC. In spite of everything, language pedagogy has emphasized the development of linguistic and discourse competencies before considering the importance of language awareness and cultural awareness. But, there is no more doubt. In language education, social thought is omnipresent. Learners, when confronted with real-life situations and cultural experiences, have to work from their own cultural representations and those offered in the textbooks or introduced by the teacher or the host milieu.

In that perspective, we must recognize that verbal communication saturates social life. It is the principal link to thought, interpersonal communication and cultural transmission (Krauss \& Chiu 1998). Real social relations could not exist without language. The opposite is also true. For Vygotsky (1962:51), each word is per se a generalization, a verbal act of thought and a "microcosm" of the larger social world. Language is by all means a sociohistorical phenomenon. It relies on a complex ensemble of social, historical and political considerations which shape our schema of references and our representations of other people and other cultures. As with social representations, the first function of cultural representations is to interpret reality that surrounds us, by symbolizing it, assigning meaning to it, and mentally remodeling it (Moscovici, 1961, 1976).

In reference to social thought, the question is: How do we develop cultural representations?

Cultural representations are viewed as a sub-set of social representations, that is, as a system of representations where the models, beliefs, norms and values of a social group interact. Bourdieu (1982) and Sperber (1996:24, 33) define "cultural representations as a subset constituted of mental and public representations inhabiting a given social group". Beliefs, intentions and preferences are mental representations specific to individuals. Signals, utterances, texts, discourse and pictures are all public representations which have a material aspect. These representations evolve and can be influenced by individuals, events and institutions (Lussier, in press). These representations mediate positively or 
negatively an individual's perceptions of a foreign culture. Positive representations can lead to xenophilic attitudes which result in behaviors and practices which can be characterized as one of openness to another culture. Negative representations can lead to xenophobic attitudes which result in behaviors of repulsion and/or rejection of the others. Such representations develop at a very young age and are reinforced later on in school contexts.

Studies in cross-cultural psychology (Laframboise, Colemen \& Gerton 1993) as well as studies in communication (Collier \& Thomas 1988; Kim 1988) report that any form of intergroup interaction implies necessarily the junction and sharing of different symbolic systems. Individuals present important varieties in the use of language and they develop their ethnic identity as well as their representations towards other cultures according to their personal role and the characteristics of the situation (Bourhis 1979; Giles and Coupland 1991; Côté \& Clément 1994; Clément 1996). In that perspective, studies on ethnic identity linked to the social psychology of groups are important. Thus, we tend not to question the ethnic identity of learners of our generation, i.e. the characteristics shared by members of the same group and put forward in order to define themselves and to differentiate themselves from members of other groups (Doron and Parot 1991). In the same way, the study of the development of cultural representations, as a specific category of social representations, becomes essential. We need to study collective representations and individual representations (Guimelli, 1999), as well as objectal representations which are the visible elements of culture, and mental representations described as the invisible elements (Bourdieu, 1992; Sperber, 1996).

It is assumed that learners acquire representations of another culture through their own experience, long before coming to school. Cognitive structures and schemata are established early in the socialization process, first with the parents, the immediate family, friends and their social environment. They are constantly revised and changing due to the socio-cultural context in which they live. As mentioned by Moscovici (1984:29), "learners are committed to their culture and to deny any part of it is to deny something within their own being. Consequently, they will attempt to assimilate or anchor it within their existing categories. They fit new information into a pre-existing pattern". They do not come to class with neutral cultural representations. They have experienced diverse cultural situations through real life activities as well as through means of the media outside the school. They are confronted with the materials they study in class in reference to the target people and culture. There is constant social interaction which allows the learner to confront his/her own schemata with those presented in a new context. If the process is unconscious, learners will not 
necessarily be aware that schemata need to be changed. Learners need to be trained to seek appropriate information in order to create new schemata. Otherwise, it may lead to a sense of confusion and alienation (Duffy 2002). When they accept that other people have other schemata through which they understand their physical and social world, learners are in a position to take up, cognitively, the perspective that others have on the learners' own socially determined representations of what might initially seem to be the social and physical world (Byram \& Morgan 1994:42). But, often students hold existing schema that greatly resist change and actually interfere with instruction. These can be elicited if confronted with discrepancies (Howard 1987:193) and positive experiences in diverse interactions with other cultures. The socio-contextual models of L2 learning (Clément, 1980) postulates that L2 confidence is the key construct underlying L2 behavior. It derives from frequent and pleasant contacts with members of the other community. Most of all, it leads to ethnolinguistic vitality on the causal sequence of the language confidence process.

As pointed out by Damen (1987:40) psychocultural influences are cognitive. But, sociocultural influences are affective factors that have an effect on communication. These affective factors are related to social organization such as role, status and other socially influenced relationships which cannot be denied and have to be considered. There are many different influences at stake in the study of cultural representations. Singer (1982:54) states that "a man behaves as he does because of the ways in which he perceives the external world".

\section{Culture and the development of intercultural communicative competence}

The statement of the problem is: When teaching languages, the development of intercultural communicative competence is not considered to be a crucial and essential component of communicative competence.

Current research suggests that education should be the entry into culture; the "culture of education" being seen as socialization into cultural ways of knowing, believing, doing and valuing (Bruner, 1996). Based on this assumption, more and more, schools are viewed as institutions that must foster social cohesiveness and promote values and attitudes that will be accepted by diverse communities. Is it possible, with a collaborative approach among educators, to help new generations of young students of all ethnic groups develop positive and critical openness to other cultures, based on mutual respect and even empathy? Could educators have a major impact on such issues? Could educators develop a systematic approach to the design of curricula, the integration of new pedagogical methodologies and the elaboration of new contents in textbooks? 
The International Encyclopedia of the Sociology of Education (1997) mentions the existence of more than one hundred and sixty-four definitions of culture. Not all definitions are relevant to research studies in the field of language education. In a socio-constructivist approach where the learner is engaged in the learning process in authentic learning situations, definitions linked to anthropology, sociology or social psychology seem of interest to educators.

In 1871, Tylor defined culture as 'that complex whole which includes knowledge, beliefs, arts, morals, law, customs, and any other capabilities and habits acquired by a man as a member of a society. Almost one century after, Goodenough adds another dimension to the definition (1964:36). 'A society's culture consists of whatever it is one has to know or believe in order to operate in a manner acceptable to its members. Culture is not a natural phenomenon; it does not consist of things, people's behavior or emotions. It is rather an organization of these things. It is the form of things that people have in mind, their models of perceiving, relating, and otherwise interpreting them. Culture is therefore knowledge, but it is knowledge which is shared and negotiated between people, belonging to all of them, and not being idiosyncratic to any single one'. For Geertz (1975) 'culture as a historically transmitted pattern of meanings embodied in symbols, a system of inherited conceptions expressed in a symbolic form by means of which men communicate, perpetuate and develop their knowledge about attitudes towards life'.

Weaver (1986) defines culture within the iceberg analogy of culture as understanding and coping where cross-cultural adjustments and stress is of great importance. It visualizes the development of cultural identity in an environment where an individual has to interact with Otherness, with other cultures in another language. The external culture refers to the observable behaviors which reflect the other cultures. These elements are visible and we can act upon them. They include words, habits, customs, etc. They are explicitly learned, conscious, easily changed and objective knowledge. They are linked to cognitive and declarative knowledge. In counterpart, when two cultural identities meet, each brings its system of thinking, values and beliefs. Most of the time, they differ. These are to be considered as the internal culture. They are implicitly learned, unconscious, difficult to change and represent subjective knowledge. They shape our presumptions, perceptions of the world and ways of thinking. They are linked to the existential knowledge or affective domain and are referred to as invisible elements. A few years later, Brown (1991: 40) defines culture as mental, behavioral and material. 'Culture consists of the conventional patterns of thought, activity and artifact that are passed from generation to generation in a manner that is generally assumed to involve learning rather than specific genetic 
programming'. Culture may also be transmitted horizontally between individuals and collectivities. Anthropologists and other researchers think of culture as a sort of supra-individual entity in itself, or as something dictated by that supraindividual entity called 'society'. There are, thus, many contexts in which "social" and "cultural" are used interchangeably. For example, language has often been thought of as closely related to or even a very important part of culture because any languages possess many conventional traits that are transmitted within populations much as culture is transmitted, and because any language has a close relationship to the culture of its speakers.

Tomalin \& Stempleski (1993) in reference to Robinson's model (1985) present a model of culture based on the teaching of three elements. The first element, "products". includes literature, folklore, art, music and artifacts. The second element "behavior" refers to customs, habits, dress, foods and leisure. The third element "ideas" is concerned with beliefs, values and institutions. This model is static but does account for the integration of the elements of "big C" (achievement culture) and "little C" (behavior culture). This restricted model served as guidelines to the development of cultural activities in the classroom and should not be considered as a model since it presents only categories of fragmented elements.

More recently, the United Nations Educational, Scientific and Cultural Organization (UNESCO, 2002) described culture as follows: ‘... culture should be regarded as the set of distinctive spiritual, material, intellectual and emotional features of society or a social group, and that it encompasses, in addition to arts and literature, lifestyles, ways of living together, value systems, traditions and beliefs'. They emerge through the interactions between individuals. It seems that to better understand another culture as a different culture it becomes important to take into consideration the discovery of the cultural specificity of the 'Other'. It becomes unthinkable to approach the cultural dimension without considering interculturalism.

As defined, culture is neither an innate process nor an automatic byproduct of language learning nor an aptitude. To reach an understanding of other cultures, we must understand the cultural specificity of "Otherness". It is essential to have strategies to manage confrontation among cultures and to encourage the discovery of similarities and acceptance of differences. It is also essential to transcend particularisms and value positive attitudes towards others, by. working on changing negative behaviors and attitudes. This social nature of learning rests on the learner's integrativeness, referring to exposure, understanding and empathic response towards other cultures. In fact, learning, as an agent of enculturation, depends on a strong endorsement of the learner's first 
language identity. The development of such relationship between confidence, self-identity and positive cultural representations towards other cultures initiates trans-cultural interpretations from the learners. It leads to the ability to act as a mediator in intercultural misunderstanding or conflict situations. 'Cultural mediators are in a position to actively combat discrimination by using antidiscrimination behaviors' (Rubenfeld, Clément, Lussier and al., 2007). Consequently, the development of language competence derives from the development of an authentic intercultural communicative competence that embodies all the different cognitive, psychological and affective factors to influence the construct of language, thought and culture.

One question remains, Which elements of culture should we include in the development of 'intercultural communicative competence'? Knowledge as acquired by transmission? A collective reality? An awareness of the Other and of the target culture? We ask schools to educate students about citizenship and to make them aware of collective stakes, whereas, transforming knowledge into attitudes and values requires educators to broaden the learner's perceptual horizon. Learners must organize the information at different levels of awareness that may result in changes through their socialization processes in and outside different contexts. Language teaching contexts seem appropriate for examining otherness. Such teaching helps learners to reinterpret their own behaviors and confront them with those they see in other cultures. To that effect, language teaching may claim a significant role in educating future generations (Byram, 1992). This discipline favors contacts with the other culture. But, there is a need to base language learning and the approach to another culture on conceptual foundations and a logical coherence (Lussier, 1997). Linear views of discursive social practices cannot lead to a coherent and integrated epistemology of Otherness. The development of a common conceptual framework in ICC, as the exiting Common European Framework of Reference, is essential. It would give guidelines to teachers and educators to work with young learners systematically in order to positively influence their schemata of other cultures and to create social and educational contexts for dialogue. This could result in positive changes for future generations and in the development of positive representations of other cultures that would lead to discursive positions and to a better construct of a social identity. Such changes take a great deal of time.

Since the socialization process starts at birth, it is important to start working early with young learners because they are still influenced by different sources such as the media and their friends. By acting on knowledge, both declarative and procedural knowledge, we may act on the social world: language power being based on schemata of perception and thought (Bourdieu, 1994). In a 
context where geo-political interests predominate, cultural issues cannot be ignored anymore. The effects of cognitive, psychological and affective factors on language communication seem essential and they are basic to the development of positive cultural representations. Being educators, we must learn how to work on changing negative behaviors and attitudes. It is now time to develop a new approach of communicative competence based on a common conceptual framework of reference that would consider language, thought and culture as essential elements to the development of an intercultural communicative competence'. Definitions of intercultural communication need to be adjusted to reflect intercultural competence.

'Intercultural communication' has been defined by Damen (1987:23) as acts of communication undertaken by individuals identified with groups exhibiting inter-group variation in shared social and cultural patterns. For Fantini (2000:28), intercultural communication is defined in terms of constructs. Knowledge, skills and language proficiency are now in association with awareness and attitudes. To be efficient, an 'intercultural speaker' would show: respect, empathy, flexibility, patience, interest, curiosity, openness, motivation, a sense of humor, tolerance for ambiguity, and a willingness to suspend judgment. All these elements represent different representations but they should be related to affective or cognitive influences. 'Intercultural competence", as identified by Meyer (1991:136), is more complex. It is "the ability of a person to behave adequately and in a flexible manner when confronted with actions, attitudes and expectations of representatives of other cultures; adequacy and flexibility implying an awareness of the cultural differences between one's own and the other cultures and the ability to handle cross-cultural problems which result from these differences'. Byram and Fleming (1998:9) also use 'intercultural competence' which is 'the knowledge of one, or, preferably, more cultures and social identities and the capacity to discover and relate to new people from other contexts for which they have not prepared directly'.

Lussier, Golubina, Ivanus and al. (2007) define 'intercultural competence' as the ability to interact effectively with people from cultures that we recognize as being different from our own, knowing that cultures simultaneously share and differ in certain aspects, e.g. knowledge, beliefs, habits and values. It infers the ability to cope with one's own cultural background in interaction with others. In a wider sense, it involves the use of significantly different linguistic codes and contact with people holding significantly different sets of values and models (Beneke, 2000). As specified by Lussier (1997) Intercultural communicative competence is based on knowledge, skills and certain attitudes in addition to linguistic, sociolinguistic and discourse 
components which define communicative competence. To reach such competencies, it is essential to come with a construct of the dominant concepts and integrate these into a common conceptual framework of reference. The goal in developing such a framework is to link the key concepts that constitute, define and clarify a discipline or a research domain. In this context, the goal is to establish the foundations of the ICC conceptual framework, to identify the existing theories and models and, finally, to clarify the interrelations between the concepts and the terms associated to the development of intercultural communicative competence. All these different stages in the process will justify the dimensions and sub-dimensions of the conceptual framework.

\section{A CONCEPTUAL FRAMEWORK OF ICC}

Lussier (1997) proposed a conceptual framework on the development of intercultural communicative competence in the context of a research project aiming at understanding the construct of cultural representations in the Canadian linguistic context. One of the issues was to consider the concepts of xenophilia and xenophobia as a continuum and the tendency for one individual to place himself/herself along this continuum, expressing either positive cultural representations (linked to xenophilia) or negative representations (linked to xenophobia). The results ${ }^{4}$, after a first survey administered to nine hundred young adults, tend to reject this linear assumption and to suggest the possibility for each individual to respond differently, positively or negatively, according to the different contexts he/she is exposed to (Lussier, 2001). According to these studies, a few adjustments were made to the original framework and it led to the present conceptual framework (Lussier, 2009). It represents an attempt to determine the feasibility and practically of teaching and assessing what everyone refers to as "intercultural communicative competence". It builds on the principles grounded to the fields of language teaching and the new areas of disciplines such as social sciences, anthropology and ethnography. By no means, it is to be seen as a linear progression. The framework depicts characteristics on a heuristic level whose process in reality runs forwards and backwards, and in all directions. Such frameworks are crucial if we are to establish clear statements. They lead

\footnotetext{
${ }^{4}$ The conceptual framework on the construct of cultural representations was first submitted to the judgement of experts from the field of testing, social sciences and didactics. Then, the component in reference to existential knowledge was validated using a written survey instrument which was administered to French-speaking young adults from 18 to 22 year old (Lussier 2000- N: 550 students) and the year after to an English-speaking population (Author and al. 2001-N: 520). The reliability coefficients were highly significant (Global alpha: 0,$91 ; 1^{\text {st }}$ sub-dimension: 0,$90 ; 2^{\text {nd }}$ dimension: 0,$91 ; 3^{\text {rd }}$ sub-dimension: 0,87 ).
} 
educators to the use of more useful and effective language, and allow more valid and reliable evaluation of such competence.

The conceptual framework is composed of three competencies: 1) intercultural cognitive competence based on knowledge, 2) intercultural procedural competence based on skills (know-how), 3) and intercultural existential competence (being) in reference to affective and psychological factors. It also takes into account existing theories and models (see Lussier, 2009 for theoretical bases of the conceptual framework).

\section{Domain of 'Cognitive knowledge'}

Knowledge competence, associated to cognitive factors, is oriented to the acquisition of information. It implies three approaches to teaching, each of them having the same relevance: the humanistic approach, the sociocultural approach and the anthropological approach (Lussier, 1997).

\section{The humanistic approach}

This approach refers to knowledge of the world linked to collective memory. This dimension includes the acquisition of formal and explicit knowledge. 'Culture' is defined as high culture or artistic culture with capital " $\mathrm{C}$ ", the heritage of civilization and thought.

\section{The sociocultural approach}

This approach refers to knowledge linked to the socio-cultural context. It considers culture as a social phenomenon. It relies on documents aiming at giving facts, statistics and social data on a specific subject. It is based on information that each individual should learn about a given culture in order to adjust to diverse cultural contexts. It includes knowledge of the target society and culture of the spoken language communities; their interpersonal relations between classes, sexes, generations, races; political and religious groupings or institutions, as well as major values, beliefs and attitudes regarding regional cultures, national identity and minorities. Such factual information is the reference to any real and impartial comparison with other societies.

\section{The anthropological approach}

This approach refers to knowledge linked to the diversity in ways of living and thinking. It is centered on human beings and their way of coping with different situations in different contexts. This type of knowledge refers to the daily life or as culture with a small "c", often referred to as behavioral culture. It 
encompasses similarities and distinctive differences between one's own world and world of the Other and other cultures. It includes habits and customs, institutions and norms, expectations, moral and legal codes, stereotypes, expressions of folk-wisdom, politeness conventions, register differences, dialects and accents, etc.

\section{Domain of skills or 'procedural knowledge'}

Skills are the use of knowledge in real life situations. It is the process of acquiring the 'knowing-how' or 'savoir-faire' when developing intercultural communicative competence. Three levels of skills have to be considered: functioning in the target language 'linguistically' speaking, adjusting and interacting to social and cultural environments, and finally integrating language to social environment and negotiating interactions.

\section{Functioning in the target language 'linguistically' speaking}

It refers to the development of practical skills as defined in the different models of communicative competence and described previously in terms of 'language skills' (Canale 1983; Bachman 1991; Council of Europe 2001). They are generally acquired in the classroom context; the foreign or second language classroom being a specialized context to learn the target language. So far, functioning in the target language has been largely limited to linguistic, discourse and sociolinguistic features. In this new era, there should be more attention given to the semantic structures of language and mostly to the integration of a semiotic analysis of texts and discourse in the classroom. As previously mentioned, the analysis of a text is about "subtextuality"; that is, the analysis of the hidden messages and values that are transmitted through cultural artifacts, attitudes or images that learners are confronted with from day to day.

\section{Adjusting to social and cultural environment}

At this second level of competence, the individuals need to experience learning out of the classroom through plurilingual and pluricultural practices in various cultural and social environments. They need to adapt cognitive knowledge and language skills to real life situations in order to adjust properly their behaviors and to be able to interact efficiently in the target language and culture. It involves explicit and implicit competence while adjusting their linguistic competence to a variety of sociocultural contexts. To that effect, interlinguistic and intercultural exchange program (Lussier, 1984) or residence abroad (Cain, 1990; Byram, Esarte-Sarries and Taylor, 1991) are the best means to influence the development 
of intercultural communication. Independent learning is also a possibility and can be subsequent to or simultaneous with classroom and fieldwork.

\section{Interacting in the target language and culture}

At this third level of competence, learners should master the language 'linguistically' and 'culturally'. 'Interacting' is perceived as the development of intercultural skills to emerge from learning and experiences in a target language and cultural environment. It even brings the learner to a meta analysis of language which leads to a reflective stage of discourse and the capacity of intercultural argumentation and interpretation. Learners are able to decode messages which can carry different interpretations. They are able to negotiate conflicts and situations of misunderstandings.

\section{Domain of 'existential knowledge' - being}

'Existential knowledge', focuses on the development of attitudes and cultural representations which shape our vision of the world and the values developed when constructing self-identity. It refers more specifically to the psychological and affective dimensions of learning. It underlies the intrinsic dimension of xenophobia (rejection of others and other cultures) and xenophilia (openness to others and other cultures). It draws upon three sub-competencies: cultural awareness, critical appropriation, and transcultural interpretation.

\section{Cultural awareness}

The concept of "cultural awareness" is defined as the promotion of understanding of and respect for other cultures, the ability to see all cultures, one's own and foreign, as the historically transmitted result of a community's history, mentality and living conditions (Menecke 1993). It implies the development of sensitivity and consciousness to others and other cultures. The language medium can be either L1 and/or L2. For Cushner and Brislin (1996), it is the ability to go beyond one's predetermined expectations and be open to new experiences.

So far, in syllabus design and language pedagogy, teaching objectives have been limited to 'cultural awareness' and are very rarely defined in terms of learning outcomes. In textbooks, it is the norm to emphasize this first level of competence and to neglect the other two levels.. As often criticized by Kramsch (1993) this presents fragmented elements of culture. It is the "fifth wheel of the wagon", a capsule of learning at the end of a unit or a specific unit totally independent from other learning units. This level was an important move to foresee fifteen years ago. It is now essential that language pedagogy goes beyond 
this in order to look at discourse as social interaction and verbal thoughts as culturally and historically predetermined.

\section{Critical appropriation}

Critical appropriation is concerned with the perception of the self-culture and other cultures. It is being able to accept and interpret self-knowledge and selfidentity, with respect for values held by other cultures and individuals from different beliefs. It concerns the internal culture, the values, thoughts and patterns implicitly learned (Weaver, 1986). It implies an analysis of the knowledge previously learned (Bloom, 1956). It supposes a positive response from the learner and the placing of value on other cultures (Krathwolh, Bloom and Masia, 1964). It aims at preventing overgeneralization, and allows for consultation, negotiation, presentation of nuanced points of view and tactful discussions of different and similar cultural customs. It leads to critical pedagogy (GuilhermeDurate (2000: 37 ) since it refers to the process by which the teachers and learners negotiate and produce meaning. It seems to be an important tool for demystifying surface and social expressions. It reaches for thick cultural representations and for mutual understanding through argumentation and justification (GuillermeDurate, 2000: 131). The confrontation and the argumentation with another culture in the person of foreign interlocutors require a re-ordering of perceptions at a level of socialization.

\section{Transcultural competence}

This higher level of competence implies 'the integration of new values, the respect of other values and the valorization of Otherness which derives from the coexistence of different ethnic groups and cultures evolving in a same society or in distinct societies while advocating the enrichment of identity of each culture in contact (Lussier, 2008). It implies the internalization of a system of values and personal disposition towards other cultures, and thus demands in-depth analysis or metacognitive analysis of other cultures from individuals. The individual becomes a critical intercultural speaker (Guillerme-Durate, 2000:203) whose predominant characteristic is defined as the ability to interrogate, explore, even evaluate while keeping his point of view restricted, situated and keeping in mind any perspective from universal validity. The individual is aware of the multiple, ambivalent, resourceful and elastic nature of cultural identities in an intercultural encounter. He perceives both concepts, the nation and the ethnic group, in terms of their origins and their present developments. Finally, he is aware that the development of ethnic identities, national or otherwise, involves a constant negotiation. He also has the ability of a cultural mediator to locate himself in a 
cultural debate - to accept the validity of different viewpoints - to use his/her imagination to provide a suitable solution which does justice to both, stabilizing one's self-identity (Byram \& Fleming, 1998).

\section{RESEARCH IN LANGUAGE EDUCATION}

Recent research in the Canadian context has focused on cultural representations, ethnic identity and intercultural competence (Lussier, Auger, Clément, LebrunBrossard, M., 2000-2008; Lussier, 2001, Amireault et Lussier, 2007). During this research process, more than 2000 young adults at the college and university levels and 200 immigrant adults learning French answered a written questionnaire and 200 accepted an oral individual interview to discuss the development of these three factors. Participants were from French speaking and English speaking regions of both Montreal and Ottawa. They were born in Canada or had immigrated to Canada with their parents. The sampling represents an important range of cultural origins. At this point in time, there are some issues that can be addressed on the development of ICC among these young adults and their cultural representations towards the different ethnolinguistic and ethnocultural individuals that they see frequently; that is, French speaking people for English speaking individuals or vice versa. The data collections reveal some similarities for both populations, mostly in these two regions of Canada where French and English are confronted in the daily life of these individuals. Most of them are aware that language is the major cultural marker of identity in Quebec.

Most participants who are from immigrant origins speak at least another language, other than French and English, which is mainly their mother tongue. It is strongly associated with family, cultural heritage and roots. Data allow us to think that participants consider their first language as their identity marker and an element of belonging. But beside these facts, English is perceived as the language of communication that they use daily with people they see mostly. They have positive representations. English is defined as familiar, comfortable and is associated with home and childhood. On the other end, French is the object of diversified cultural representations. It is seen as essential to work in Quebec but the obligation to learn it is perceived negatively. In terms of social interactions, it is interesting to mention that Montreal English speaking youth realise that their competence is French is too low and does not allow them to integrate into the French speaking community. As such, being part of the linguistic minority may result in increased barriers to communication and education, a sense of exclusion and isolation, not to mention the development of negative representations. As individuals, they don't feel at ease. They feel stressed. They are afraid of being badly judged by French speaking students for 
not being competent enough to face any contextual situations. Similar to immigrants, they consider themselves as strangers, from a minority group. They don't think that they can integrate into the French community. This has caused English-speaking Quebecers to re-examine their place in Quebec. As mentioned in the QCGN survey report (2009:5,10), progress will occur through efforts to increase their level of bilingualism and to address barriers to community participation. Finally, the participants, who mention that they feel comfortable in a French speaking milieu, often use French in their daily life or have French speaking persons as relatives.

In terms of influential factors, the development of cultural representations is not a linear process. They are influenced by the individuals they meet and events that they experience. Many of the participants mention Bill 101 and conflicts that they experienced with other students in the school yards or within sport clubs. The discrimination in such events let indelible marks. However, contacts with individuals seemed to have more influence on the development of their (inter)cultural representations than any negative events that they had experienced. Positive contacts with friendly and kind French speaking Quebecers are effective to counterbalance the negative cultural representations they often carry.

Comments from different participants need to be taken into consideration. They reveal that despite the different contextual situations they have experienced, they do not belong to either culture, English or French. It is a hybrid identity process which is associated with the different cultures they have integrated and which are recombined and constantly questioned (Pieterse, 1995; Amireault, 2007). As one student mentions: 'I am someone in the middle bringing two cultures together'. Another student mentioned that he was between two cultures; that there is no return to his culture but no other culture to identify himself within.

\section{CONCLUSION}

It is common knowledge to believe that to favour contacts between (inter)cultural groups will contribute to generating intercultural understanding. Boechner (1982) mentions that, on the contrary, intergoup contacts do not necessarily reduce tensions and prejudices between groups. Lussier (1984), when studying the effects of intercultural and interlingusitic exchange programs, mentions two essential conditions: 1) the planning of such programs must bring students to live together in significant situations which make them use the other language informally, in diverse contexts outside the classroom, 2) the quality of the various contacts and of pluricultural experiences, as lived through such exchanges, are an 
essential key to success. In fact, students need to integrate language and culture. More recently, Kramsch (1998) added that 'culture is difference, that variability is always a potential source of conflict when one culture enters in contact with another.' In that perspective, a third condition should be considered. Students should also be acquainted with the intercultural group they will socialize with by video or internet before participating in an exchange program.

The research seems to confirm that language, thought and culture are complementary to one another, not to say interdependent. It also reveals what is common to all participants; their ethnic identity. Further, it emphasizes the role of positive cultural representations which lead to openness to other cultures (xenophilia) and the need for educators to consider education as an essential entry to social interrelations and interculturalism.

\section{References}

Agar, M. (1994). The intercultural frame. International Journal Intercultural Religion, 18 (2), 221-237.

Agger, B. (1992). Cultural studies as critical theory. London: The Falmer Press.

Amireault, V. (2007). Représentations culturelles et identité d'immigrants adultes de Montréal apprenant le français. Doctoral dissertation, McGill University, Montréal, Québec, Canada.

Amireault, V. and Lussier, D. (2007). Représentations culturelles, expériences d'apprentissage du français et motivations des immigrants adultes en lien avec leur intégration à la société québécoise. Langues et sociétés, 45: 1-51. Québec : gouvernement du Québec.

Bachman, L. E. (1991). What does language testing have to offer? TESOL Quarterly, 25 (4), 671-685.

Bloom, B. S. (Ed.). (1956). Taxonomy of educational objectives: The classification of educational goals: Handbook 1. Cognitive domain. New York: McKay.

Beneke, J. (2000) Intercultural competence. In U. Bliesener (ed.), Training the Trainers. International Business Communication, 5:108-109. Carl Duisberg Verlag.

Bochner, S. (1982). Cultures in contacts: Studies in cross-cultural interaction. New York: Pergamon Press.

Bourdieu, P. (1982). Ce que parler veut dire. L'économie des échanges linguistiques. Paris: Fayard.

Bourdieu, P. (1992). Réponses: Pour une anthropologie réflexive. Paris: Éditions du Seuil.

Bourdieu, P. (1994). Language and symbolic power. Cambridge, MA: Harvard University Press.

Bourhis, R.Y. (1979). Language in ethnic interaction : A social psychological approach. In H. Giles \& B. SaintJacques (Eds.), Language in ethnic relations. Oxford: Pergamon Press.

Brown, D.E. (1991). Human universals. Philadelphia: Temple University Press.

Bruner, J. (1996). The culture of education. Cambridge, MA: Harvard University Press.

Byram, M. S. (1989). Cultural studies in foreign language education. Clevedon: Multilingual

Matters.

Byram, M. S. (1992). Language and culture learning for European citizenship. In M.C. Beveridge and G. Reddiford (Eds.), [Special issue] Language and Education, 6, 165-176.

Byram, M. S. (1994). Comment: Authorities and people. International Journal of Sociology of Language, 110 , 131-36.

Byram, M. S. (1997). Teaching and assessing intercultural communicative competence. Clevedon : Multilingual Matters.

Byram, M. S., Esarte-Sarries, V. \& Taylor S. (1991). Cultural studies and language learning: A research report. Clevedon: Multilingual Matters.

Byram, M. S. \& Fleming, M. (Eds.). (1998). Language learning in intercultural perspective. Cambridge: Cambridge University Press.

Byram, M. S., Morgan, C. \& al. (1994). Teaching-and-learning language-and-culture.

Clevedon: Multilingual Matters.

Byram, M. S., Zarate, G. (Eds.). (1997). The sociocultural and intercultural dimension of language learning 
and teaching. Strasbourg: Council of Europe.

Cain, A. (1990). French secondary school students' perceptions of foreign cultures. Language Learning Journal, $2,48-52$.

Calvet, L. J. (1975). Pour ou contre Saussure : Vers une linguistique sociale. Paris: Payot.

Calvet, L. J. (1993). La sociolinguistique. Collection Que sais-je ? Paris: Presses universitaires de France.

Calvet, L. J. (1999). Pour une écologie des langues du monde. Paris: PLON.

Canale, M. (1983). From communicative competence to language pedagogy. In J. Richards \& J. Schmidt (Eds.), Language and communication. London: Longman.

Canale, M. \& Swain, M. (1980). Theoritical bases of communicative approaches to second language teaching and testing. Applied Linguistics : Vol. 1., No 1, 2-43, Oxford: Clarendon Press.

Chomsky, N. (1965). Aspects of the theory of syntax. Cambridge, MA: M.I.T. Press.

Clément, R. (1979). Ethnicity, contact and communicative competence in a second language. Paper presented at an international conference on social psychology and language at the University of Bristol.

Clément, R. (1996). Social psychology and intergroup communication. Journal of Language and Social Psychology, 15, 222-229.

Collier, M. J. \& Thomas, M. (1988). Cultural identity, an interpretative perspective. In Y. Y. Kim \& W. B. Gudykunst (Eds.), Theories in intercultural communication. Newbury Park, CA: Sage.

Coste, D. (2009). Le Cadre européen commun de référence pour les langues: Contextualisation et/ou standardisation? Actes du colloque de Sèvres 2007. Revue Dialogues et Cultures, 54: 19-29 Paris, FIPP.

Côté, P. \& Clément, R. (1994). Language attitudes: An interactive situated approach. Language and Communication, 14, 237-251.

Council of Europe. (2001). Common European framework of reference for language teaching and learning. Strasbourg: Council of Europe.

Cushner, K. and Brislin, R.W. (eds) (1997) Improving Intercultural Interactions: Modules for CrossCultural Training Programs. Thousand Oaks: Sage Publications.

Damen, L. (1987). Culture learning: The fifth dimension in the language classroom. New York: Addison-Wesley.

Di Pietro, J. F., Muller, N. (2001). Que faire de la notion de représentation ? Que faire des représentations ? : Questions méthodologiques et didactiques à partir de travaux sur le rôle des représentations dans l'apprentissage d'une langue. In C. de Margerie \& D. Moore (Eds.), Les représentations et leur apprentissage : Références, modèles, données et méthodes (pp. 51-64). Paris: Didier; Saint-Cloud: ENS Fontenay.

Donmall, B. G. (Ed.). (1985). Language awareness. London: C.I.L.T.

Doron, R. and Parot, F. (Eds.). (1991). Dictionnaire de psychologie. Paris: Presses universitaires françaises.

Duffy, S. (2002). Intercultural competencies of upper secondary learners of French. Unpublished doctoral dissertation, University of Durham, School of Education.

Fantini, A.E. (2000) A central concern: developing intercultural competence. In A.E. Fantini (ed.) SIT Occasional paper series: Inaugural issue-about our institution, 23-42 Brattleboro, VT: School for International Training.

Featherstone, M. (1995). Undoing culture: Globalization, postmodernism and identity. London: Sage.

Gardner, R. C. and Lambert, W. E. (1965). Language aptitude, intelligence and second language achievement. Journal of Educational Psychology, 56, 191-99

Gardner, R. C. and Lambert, W. E. (1972). Attitudes and motivation in second language learning. Rowley, MA: Newbury House.

Geertz, C. (1975). The interpretation of cultures. London: Hutchinson.

Giles, H. and Coupland, N. (1991). Language: Contents and consequences. Milton Keynes: Open University Press.

Guilherme-Durate, M. (2000). Critical cultural awareness: The critical dimension in foreign culture education. Doctoral dissertation, University of Durham, School of Education.

Guilherme, M. (2002). Critical citizens for an intercultural world. Clevendon: Multingual Matters.

Giroux, H. A. \& McLaren, P. (1994). Between borders: Pedagogy and the politics of cultural studies. New York: Routledge. 
Goethals (2002). Peace and FL teaching. Unpublished paper. Unknown sources.

Goodenough, W. H., (1964). Cultural anthropology and linguistics. In D. Hymes (Ed.), Language in culture and society. New York: Harper and Row.

Goodenough, W.H. (1981). Culture, language, and society. Menlo Park, CA: Benjamin/Cummings.

Gudykunst, W. \& Kim, Y. (1984). Communicating with strangers: An approach to intercultural communication. Reading, MA: Addison-Wesley.

Guilherme-Durate, M. (2000). Critical cultural awareness: The critical dimension in foreign culture education. Doctoral dissertation, University of Durham, School of Education.

Guilherme-Durate, M. (2002). Critical citizens for an intercultural world. Clevendon:

Multilingual Matters.

Guimelli, C. (1999). La pensée sociale. Paris: Presses Universitaires de France.

Hall, E. T. (1969). The hidden dimension. Garden City, NY: Anchor Books/Doubleday.

Halliday, M. A. K. (1973). Explorations in the functions of language. New York: Elsevier North Holland.

Hawkins, E. (1981). Modern languages in the curriculum. Cambridge: Cambridge University Press.

Hawkins, E. (1984). Awareness of language. An introduction. Cambridge: Cambridge University Press.

Hymes, D. (1972). Towards communicative competence. Philadelphia: University Pennsylvania Press.

International Encyclopedia of the Sociology of Education. (1997). Oxford; New York: Pergamon

Jacquinot, G. (1987). Images et représentations pour une théorie de l'apprentissage par les médias. Montréal: Université du Québec à Montréal, Montréal, Québec, Canada.

James, C. \& Garret, P. (Eds.). (1991). The scope of language awareness in the classroom. New York: Longman.

Kramsch, C. (1993). Context and culture in language teaching. Oxford: Oxford University Press.

Kramsch, C. (1998). Language and culture. Oxford: Oxford University Press.

Krashen, S. D. (1976). Formal and informal linguistic environments in language learning and language acquisition. TESOL Quaterly, 10, 157-168.

Krashen, S. D. (1981). Second language acquisition and second language learning. Oxford: Pergamon.

Kratwohl, D. R., Bloom, S. \& Masia, B. B. (1964). Taxonomy of educational objectives: The classification of educational goals. Handbook 2: Affective Domain. New York: McKay.

Krauss, R. M. \& Chiu, C.-Y. (1998). Language and social behavior. In D. T. Guilbert, S. T. Fiske and G. Lindzey (Eds.), The Handbook of social psychology (Vol.2) (pp. 41-88). New York: McGraw-Hill.

Labov, W. (1966). The social stratification of English in New York City. Washington, DC: Center for Applied Linguistics.

Labov, W. (1972). Sociolinguistic patterns. Philadelphia: University of Pennsylvania Press.

Laframboise, T., Colemen, H. L. K. \& Gerton, J. (1993). Psychological impact of biculturalism: Evidence and theory. Psychological Bulletin, 114, 395-412.

Lazar, I., Huber-Kriegler, M., Lussier, D., Matei, G., \& Peck, C. (Eds.), 2007. Developing and Assessing Intercultural Communicative Competence: A Guide for language Teachers and Teacher Educators, . Strasbourg: European Centre for Modern Languages / Council of Europe.

Lenneberg, E. H. (1967). Biological Foundations of Language. New York: John Wiley.

Lussier, D. (1984). Les effets des activités d'échanges interlinguistiques sur le développement de la compétence de communication en langue seconde par enseignement traditionnel. Doctoral thesis, Quebec City: Laval University.

Lussier, D. and Turner, C.E. (1995). Le point sur... l'évaluation des apprentissages en didactique des langues. Montreal: Centre éducatif et culturel. $257 \mathrm{pp}$.

Lussier, D. (1997). Domaine de référence pour l'évaluation de la compétence culturelle en langues. Revue de didactologie des langues-cultures, ELA 231-246. Paris: Didier Erudition.

Lussier, D., Auger, R., Clément, R. and Lebrun-Brossard. M. (2000-2008). Cultural Representations, ethnic identity and intercultural communication among young adults. Ottawa: Grants from Heritage Canada and the Council of Research in Human Sciences in Canada.

Lussier, D., Golubina, K., Ivanus, D. and al. (2007) Guidelines for the Assessment of Intercultural Communicative Competence. In Developing and assessing intercultural communicative competence: A Guide for language teachers and teacher educators. Lazar, I., Kriegler. M., Lussier, D., Matei, G. and Peck C. (eds) European Centre for Modern Languages. Strasbourg: Council of Europe Publishing. 
Lussier, D., Auger, R., Urbanicova, V. and al. (2004) Representations of others and other cultures in the context of the pre-service and ongoing training of teachers. In Cultural mediation and the teaching and learning of languages. Zarate, G, Gohard-Radenkovic, A., Lussier, D. and Penz. H. (eds), Chapter 7: 181-213. European Centre for Modern Languages. Strasbourg: Council of Europe Publishing.

Lussier, D. (2009) Common reference framework for the teaching and assessment of 'Intercultural Communicative Competence'. In Studies in Language Teaching, ALTE 2008, 13: 234-244. Cambridge: Cambridge University Press.

Lussier, D. (in press). Theoretical bases of a conceptual framework of reference to intercultural communicative competence. Journal of Applied Linguistics. Cambridge: Cambridge University Press.

Lussier, I. (2001) Validation du questionnaire «xénophilie/xénophobie » dans le contexte des représentations culturelles auprès d'adolescents montréalais. Master thesis, Montreal: Université du Québec à Montréal.

Malinowsky, B. (1923). The problem of meaning in primitive languages. In C. K. Ogden \& I. A. Richards (Eds.), The meaning of meaning. New York: Harcourt, Brace \& World Inc.

Melde, W. (1987). Zur Integration von Landeskunde und Kommunikation im Fremdsprachenunterricht. Tubingen : Gunter Narr Verlag.

Menecke, A. (1993). Potentialities of textbooks for teaching cultural awareness. In M. Byram, (Ed.), Germany :Its representation in textbooks for teaching German in Britain. Frankfurt A.M.: Dieserweg.

Meyer, M. (1991). Developing transcultural competence: Case study of advanced foreign language learner. In

D. Buttjes, \& M. Byram, (Eds.), Mediating languages and cultures: Towards an intercultural theory of foreign language education. Clevedon: Multilanguage Matters.

Moirand,S. (1982). Enseigner à communiquer en langue étrangère. Paris : Hachette.

Morrow, K. (1977). Teaching the functions of language. English Language Teaching Journal, 32 (1), 9-14.

Moscovici, S. (1961). La psychanalyse, son image et son public. Paris : PUF.

Moscovici, S. (1976). Social influence and social change. New York: Academic Press.

Moscivici, S. (1984). The phenomenon of social representations. In R. Farr \& S. Moscovici (Eds.), Social representations. Cambridge: Cambridge University Press.

Munby, J. (1978). Communicative syllabus design. Cambridge: Cambridge University Press

Oller, J. W. Jr. \& Obrecht, D. H. (1969). The psycholinguistic principle of informational sequence:

An experiment in second language learning. IRAL, 20, 119-23.

Penfield, W. G. (1965). Conditioning the uncommitted cortex for language learning. Brain, 88, 787-98

Pieterse, J.N. (1995). Globalization as hybridization. In M. Feathersone, S. Lash and R. Robertson (Eds.), Global modernities 45-68. London: Sage Publications.

QCGN, (2009). Creating Spaces for Young Quebecers: Strategic Orientations for English-Speaking Youth in Quebec. Quebec: Quebec Community Groups Network

Robertson, R. (1995). Globalization: Time-space and homogeneity-heterogeneity. In M. Featherstone, S. Lash \& R. Robertson (Eds.), Global modernities (pp. 25-44). London: Sage.

Rubenfeld, S., R. Clément, D. Lussier et al. (2006). Second Language Learning and Cultural Representations: Beyond Competence and Identity. Language Learning, 56 (4), 609-632.

Rubenfeld, S., Clément, R., Vinograd, J., Lussier, D. et al. (2007). Becoming a cultural intermediary: A further social corollary of second language learning. In Journal of Language and Social Psychology, 26(2:),182-203.

Sapir, E. (1934). The emergence of the concept of personality in a study of cultures. Journal of Social Psychology, 5, 408-15.

Sapir, E. (1970). Culture, language and personality: Selected essays. Berkeley, CA: University of California Press.

Saussure, F. de (1916). Cours de linguistique générale. Paris: Payot

Savignon, S. J. (1972). Communicative competence: An experiment in foreign language teaching. Philadelphia: Center for Curriculum Development.

Seelye, H.N. (1992). Teaching Culture: Strategies for Intercultural Communication.

Lincolnwood, Ill.: National Textbook.

Seelye, H. N. (1982). Teaching culture: strategies for foreign language educators. Skokie, IL: 
National Textbook.

Seelye, H.N. (1973). Teaching the Foreign Culture : a Context for Research. In J.R. Green (Ed.)

Foreign Language Education Research: a Book of Readings Skokie, Ill.: Rand McNally, pp. 74-89.

Singer, M. (1982). Culture: A perceptual approach. In L. Samovar \& R. Porter (Eds.), Reprinted from D. Hoopes (Ed.), Readings in intercultural communication, Vol.1.

Skinner, B.F. (1957). Verbal Behavior. New York:Appleton-Century-Crofts.

Sperber, D. (1996). Explaining culture, a naturalistic approach. Oxford: Blackwell Publishers.

Stern. H.H. (1983). Fundamental Concepts of Language Teaching. Oxford: Oxford University Press.

Tomalin, B. \& Stempleski, S. (1993). Cultural awareness. Oxford: Oxford University Press.

Tucker, G. R. (1974). Methods of second language teaching. Paper presented at the Federal Conference on Bilingual Education, Halifax, New Brunswick, Canada.

Tylor, E.B.( 1971). Primitive culture: researches into the development of mythology, philosophy, religion, art and custom. London: J. Murray.

UNESCO (2001). Déclaration universelle sur la diversité culturelle. Paris : UNESCO.

Upshur, J. A. (1968). Problems and tests. On Problems in Foreign Language Testing: Proceeding of a Conference, Language Learning, 18 (8).

Van Dijk, T. A. (1997). Discourse as social interaction. London: Sage Publications.

Van Dijk, T. A. (1998). Ideology, a multidisciplinary approach. London: Sage Publications.

Van Ek, J. A. (1976). Significance of the threshold-level in the early teaching of modern languages. Council of Europe: Symposium on Modern Languages in Primary Education. Bakkerne, Holte.

Vygotsky, L. S. (1962). Thought and language. Cambridge, MA: M.I.T. Press.

Vygotsky, L. S. (1971). Mind in society. Cambridge, MA: Harvard University Press.

Weaver, G. (1986). Understanding and coping with cross-cultural adjustment stress. In R. M.

Page (Ed.), Cross-cultural orientations: New conceptualizations and applications. London:

University Press of America.

Widdowson, H. (1978). Teaching language as communication. Oxford: Oxford University Press. Wiegand, P. (1992). Places in the primary school. London: Falmer Press.

Denise Lussier, Professor Emerita McGill University, Eductional Psychologist and Docimologist does research in the areas of intercultural communicative competence in education, measurement and evaluation, and development of curriculum; she can be contacted at denise.lussier@mcgill.ca 